\title{
PENDERITAAN DALAM KONTEKS PENGINJILAN
}

\author{
Tri Prapto Suwito, Yanto Paulus Hermanto, Yulia Jayanti Tanama \\ Sekolah Tinggi Teologi Kharisma Bandung \\ trigon59@yahoo.com,yantopaulush@gmail.com,yuliatanama@gmail.com
}

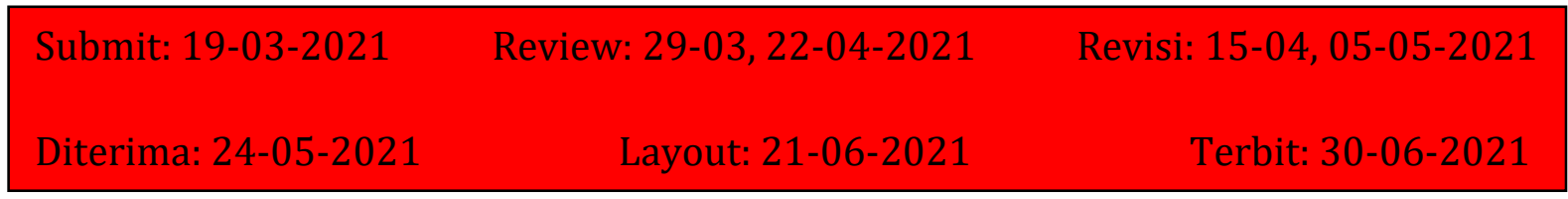

\begin{abstract}
Evangelism and suffering are two things that are often questioned. What is the connection between evangelism and suffering? Why do these two things always seem to go hand in hand? This issue is often debated. The author conducts research with a qualitative approach, and it is hoped that from various historical sources, books and journals related to this issue, research results can be obtained that can answer this problem and become the basis for Christians to respond correctly according to the truth of God's Word. Evangelism is a must for believers, but on the other hand suffering seems to be allowed by God for evangelists to experience. Both of these things must be addressed correctly by all believers, so that the lives of believers still obey His commands but in His presence that continues to strengthen and make them happy.
\end{abstract}

Keywords: Salvation; Power; Martyr; Sacrifice; Evangelism; God's Inclusion.

\begin{abstract}
Abstrak
Penginjilan dan penderitaan merupakan dua hal yang sering kali dipertanyakan. Apa kaitan penginjilan dan penderitaan? Mengapa kedua hal tersebut seakan selalu berjalan beriringan? Masalah ini sering menjadi perdebatan. Penulis melakukan penelitian dengan pendekatan kualitatif, dan diharapkan dari berbagai sumber sejarah, buku dan jurnal yang terkait dengan masalah tersebut diperoleh hasil penelitian yang bisa menjawab permasalahan ini dan menjadi dasar bagi orang-orang Kristen untuk merespons dengan benar sesuai kebenaran Firman Tuhan. Memberitakan Injil merupakan perintah dari Tuhan Yesus bagi orang percaya, namun di sisi lain menderita menjadi bagian yang Tuhan ijinkan bagi para pemberita Injil. Kedua hal ini harus disikapi dengan benar oleh semua orang percaya, sehingga hidup orang percaya tetap mentaati perintah-Nya namun dalam penyertaan-Nya yang terus menguatkan dan membahagiakan.
\end{abstract}

Kata-katakunci:Keselamatan;Kuasa;Martir;Pengorbanan;Penginjilan;Penyertaan Tuhan.

\section{Pendahuluan}

Ada beberapa faktor yang menyebabkan seseorang mau memberitakan injil. Pertama, karena mereka sadar bahwa Tuhan telah terlebih dahulu mengasihi mereka, sehingga mereka memiliki keyakinan akan keselamatan yang diberikan-Nya. Kedua, 
Tanama)

karena kasih Allah memenuhi hatinya, sehingga dia mengasihi juga orang-orang yang belum percaya. Ketiga, Roh Kudus yang ada dalam hati mereka memberikan dorongan untuk melaksanakan amanat agung-Nya. ${ }^{1}$ Keempat, dia menyadari bahwa kalau seseorang diberi kesempatan untuk memberitakan Injil, itu adalah karena anugrah Allah (1Tes. 2:4), sehingg orang tersebut memberitakan dengan sukacita. Jika faktor-faktor ini yang menjadi alasannya maka setiap orang percaya akan bergerak dalam penginjilan. Seperti yang disampaikan rasul Paulus: "Celakalah aku, jika aku tidak memberitakan Injil." (1Kor. 9:16). ${ }^{2}$

Elvin Atmaja Hidayat menuliskan tiga keburukan yang bisa mengakibatkan penderitaan. Pertama adalah keburukan fisik. Keburukan ini berkaitan dengan penderitaan jasmani. Kedua, keburukan metafisik. Keburukan ini ada karena akibat dari bencana alam. Bencana alam yang terjadi mengakibatkan penderitaan. Ketiga, keburukan moral. Keburukan ini adalah dampak langsung dari tindakan jahat sesama manusia. $^{3}$

Penderitaan berasal dari berbagai sumber. Setiap orang menghadapi penderitaan dengan keadaan yang berbeda-beda. Penderitaan itu akan membuat seseorang merasa tidak nyaman. ${ }^{4}$ Keadaan itu akan membuat seseorang mengambil keputusan, apakah tetap bertahan dalam keadaan tersebut ataukah pergi menjauh mencari keadaan yang lebih menyenangkan.

Namun dalam sejarah banyak orang yang melakukan penginjilan ternyata hidupnya susah, menderita bahkan ada yang mengalami kematian yang mengerikan, seperti Stefanus (Kis. 7: 56), Polikarpus dan murid-murid Tuhan yang lainnya."(Kis. 7:56). ${ }^{5}$ kegiatan penginjilan tidak memberikan jaminan seseorang akan hidup aman dan sentosa. Kenyataan ini membantah pendapat dari teologi sukses, yang beranggapan bahwa keputusan mengikut Yesus adalah hal yang menyenangkan karena tidak akan mengalami penderitaan. ${ }^{6}$

Menjadi pertanyaan mendasar, Mengapa mereka yang melakukan penginjilan umumnya menderita, mengalami kesulitan bahkan mengalami kematian yang mengerikan. ${ }^{7}$ Namun menurut Paulus, menderita karena Injil bukanlah tanda kegagalan, melainkan tanda kemenangan. Pada saat yang sama, menderita karena Injil adalah anugerah, karena tidak semua orang bisa menderita untuk-Nya. Penderitaan akan selalu menjadi bagian hidup seseorang yang melakukan penginjilan.

Melihat kenyataan ini, maka penulis melakukan penelitian untuk menjawab Apa kaitannya Penginjilan dan Penderitaan? Apakah dua hal ini selalu beriringan dan tidak dapat dipisahkan? Dan setelah mengetahui hal tersebut bagaimana respons orang Kristen seharusnya. Apakah penginjilan akan selalu beriringan dengan penderitaan

\footnotetext{
${ }^{1}$ Wijaya Hengki and Nyoman Lisias F. Dju, "Pengajaran Tentang Panggilan Berdasarkan Kitab Yunus," ResearchGate (2015): 92.

2Yushak Soesilo, "Pentakostalisme Dan Aksi Sosial: Analisis Struktural Kisah Para Rasul 2:41-47," DUNAMIS: Jurnal Teologi dan Pendidikan Kristiani (2018).

${ }^{3}$ Elvin Atmaja Hidayat, "Iman Di Tengah Penderitaan: Suatu Inspirasi Teologis-Biblis Kristiani," Melintas An International of Philosophy and Religion 32, no. 3 (2016): 285-308, https://journal.unpar.ac.id/index.php/melintas/article/view/2695.

${ }^{4}$ Lewi Nataniel Bora, "Keserupaan Dengan Yesus Dalam Penderitaan, Kesengsaraan Dan KematianNya,” Manna Rafflesia 7, no. 1 (2020), https://journals.sttab.ac.id/index.php/man_raf/article/view/127.

${ }^{5}$ Djuwansah Suhendro P Stephanus, "Mengajarkan Penginjilan Sebagai Gaya Hidup Orang Percaya," Redominate (2019).

${ }^{6}$ Jonidius Illu, "PENDERITAAN DALAM PERSFEKTIF ALKITAB," Luxnos: Jurnal Sekolah Tinggi Teologi Pelita Dunia 5, no. 2 (2019): 101-109, https://luxnos.sttpd.ac.id/index.php/20_luxnos_20/article/view/19.

7F. D. Wellem, "Polikarpus," BPK Gunung Mulia, 213-214.
} 
orang Kristen? Hal ini menjadi sesuatu yang menjadi landasan utama penelitian yang dilakukan oleh penulis.

Penulis melihat bahwa penelitian ini unik, karena belum pernah ada yang meneliti, kalaupun ada umumnya penderitaan sebagai orang Kristen bukan sebagai penginjil. ${ }^{8}$ Atau pun meneliti tentang penginjilan tidak dikaitkan dengan penderitaan. ${ }^{9}$ Tujuan penelitian ini untuk mengetahui sejauh mana kaitan penginjilan dan penderitaan.

\section{Metode Penelitian}

Penulis melakukan penelitian dengan metode pendekatan kualitatif deskriptif. Penulis mengumpulkan semua buku dan jurnal yang berkaitan dengan penginjilan dan akibatnya, serta penderitaan yang dialami oleh para pemberita Injil. Sehingga dengan demikian dapat ditarik suatu kesimpulan apakah ada kaitannya antara penginjilan dan penderitaan yang mungkin dialami tersebut. ${ }^{10}$

Penulis juga melihat berbagai sejarah yang terjadi, khususnya berkaitan dengan penginjilan dan akibat yang terjadi terhadap para penginjil tersebut. Juga kisah dan perkataan dari Alkitab yang berkaitan untuk menjawab rumusan masalah.

\section{Pembahasan}

\section{Penginjilan}

Apakah yang disebut Penginjilan? Penginjilan adalah suatu pelaksanaan pemberitaan tentang Yesus. Kehidupan, kematian, kebangkitan, kenaikan ke surga, kembali ke bumi dan karya-Nya bagi manusia, itulah yang disampaikan(1Kor. 15:3-4). Kemudian mengajak mereka untuk percaya dan menerima pemberitaan tersebut dan bertobat dari semua dosa (Kis. 26:18) serta percaya kepada Kristus dan mau menerimaNya sebagai Tuhan dan Juruselamat secara pribadi dalam hidupnya, supaya mendapatkan kehidupan yang kekal (Yoh. 20:30-31). Penginjilan juga merupakan perintah dari Yesus Kristus kepada murid-murid-Nya. ${ }^{11}$

Sejak manusia jatuh ke dalam dosa ditaman Eden Allah sudah berkehendak memulihkan manusia dengan mengatakan: "Aku akan mengadakan permusuhan antara engkau dan perempuan ini, antara keturunanmu dan keturunannya; keturunannya akan meremukkan kepalamu dan engkau meremukkan tumitnya"(Kej. 3:15). Hal ini adalah inisiatif Allah untuk mengembalikan hubungan Allah dengan manusia yang sudah jatuh ke dalam dosa. Allah mencari dan memanggil manusia (Kej. 3:9) dan ingin memakai manusia untuk memberitakan Injil keselamatan.

Pemberitaan Injil merupakan tugas dan tanggung jawab orang percaya yang telah dihapus dosa-dosanya. Oleh karena itu patutlah menolong orang lain juga untuk memperoleh keselamatan. Kebenaran hanya ada di dalam Yesus Kristus, barang siapa percaya kepada-Nya tidak binasa melainkan beroleh hidup yang kekal (Yoh. 3:16), dan hanya melalui Yesus seseorang bisa sampai kepada Bapa (Yoh. 14:6). Oleh sebab itu setiap orang percaya wajib memberitakan kabar baik ini ke sebanyak mungkin orang.

\footnotetext{
8Warseto Freddy Sihombing, "Penderitaan Orang Percaya Dalam Surat 1 Petrus," KERUGMA: Jurnal Teologi dan Pendidikan Agama Kristen (2019).

${ }^{9}$ Stephanus, "Mengajarkan Penginjilan Sebagai Gaya Hidup Orang Percaya."

${ }^{10}$ Sonny Eli Zaluchu, "Strategi Penelitian Kualitatif Dan Kuantitatif Di Dalam Penelitian Agama," Evangelikal: Jurnal Teologi Injili dan Pembinaan Warga Jemaat 4, no. 1 (2020): 28-38.

${ }^{11}$ Daud Alfons, Pandie Nidia, and Lina Ardela, URGENSI PENGINJILAN SEBAGAI TANGGUNG JAWAB GEREJA, APOLONIUS : Jurnal Teologi Dan Pendidikan Kristen, 2020.
} 

Tanama)

Dalam penginjilan ada beberapa metode yang seringkali digunakan. Metodemetode yang digunakan tersebut umumnya dirancang untuk memudahkan si pendengar untuk memahami dengan jelas dan juga dirancang agar memperkecil terjadinya perdebatan dan permusuhan. Namun demikian ketika metode-metode ini digunakan selalu saja terjadi adanya ketidaksenangan dari pihak yang diinjili. ${ }^{12}$

Peristiwa dalam sejarah memperlihatkan bahwa para penginjil mengalami penderitaan bahkan berakhir dengan kematian sebagai martir. Begitu pula apa yang disampaikan dalam Alkitab bahwa orang-orang yang memberitakan Injil mengalami penderitaan dan penganiayaan. Dalam hal ini bagi mereka yang ingin hidup di dalam Kristus tentu tidak dapat menghindari penderitaan atau bentuk penganiayaan lainnya (Mat. 5: 10-12; 10:22; Kis. 14:22; Fil. 1:29; Mat. 4:12).

Pada waktu itu ada banyak orang percaya di Yerusalem, dan di seluruh Palestina, bahkan di luar perbatasan Palestina mendapat aniaya dan siksaan. Penganiayaan bisa berupa ancaman kematian, atau menghadapi fanatisme kebencian dan kemarahan massa. Tetapi bagi para penginjil segala sesuatu yang didapatkan dari iman yang kuat sangat meneguhkan roh yang ada sehingga panggilan kekuatan mental bukanlah dari diri sendiri, melainkan karena Kristuslah yang membuat mereka bertahan dalam perjuangannya yang sangat berani.

\section{Penderitaan Bagi Para Penginjil}

Para penginjil adalah semua orang yang terbeban dan merasa sudah diselamatkan, dan mereka terpanggil untuk melakukan amanat agung Kristus. (Mat. 28:19-20). Mereka dengan rela melakukannya meskipun mengalami berbagai penderitaan dan penganiayaan. ${ }^{13}$ Penginjilan merupakan perintah yang diberikan langsung oleh Yesus ketika Dia hendak terangkat ke surga (Mat. 28:19-20; Mrk. 16:15-18, Kis. 1:8).

Contoh yang jelas adalah para murid dari Yesus sendiri. Hampir semua dari mereka mengalami penderitaan. Dalam sejarah banyak orang yang melakukan penginjilan ternyata hidupnya susah, menderita bahkan ada yang mengalami kematian yang mengerikan. Sebagai contoh: Stefanus, adalah seorang yang penuh iman dan Roh Kudus beserta dengan Filipus, Prokhorus, Nikanor, Timon, Parmenas dan Nikolaus, seorang penganut agama Yahudi dari Anthiokia, mereka terpilih untuk melayani orang miskin (Kis. 6:5). Alkitab mencatat bahwa Stefanus penuh dengan kuasa dan mengadakan mukjizat-mukjizat dan tanda-tanda diantara orang banyak (Kis. 6:8) bagaimana dengan dirinya sebagai martir pertama? Dia bukan anggota dari dua belas rasul Yesus, tetapi dia bersaksi dengan begitu hebatnya dan apakah dia tidak merasakan sesuatu? Dia dilempari batu hingga mati. Penderitaan akan selalu beriringan dengan penginjilan, Penderitaan orang Kristen dalam penginjilan merupakan bagian yang tidak terpisahkan.

Polikarpus adalah murid Yohanes yang bekerja sebagai seorang uskup di Smirna, pada pertengahan abad kedua di Asia. Polikarpus mempunyai kepercayaan sangat teguh dan hidup sangat sederhana. Karena keyakinannya kepada Yesus Kristus ia ditangkap dan dibawa ke Roma. Polikarpus diperintahkan oleh Kaisar untuk mengutuki Yesus sampai tiga kali agar ia terbebas dari hukuman mati, tetapi Polikarpus tidak mau berbuat itu. Imannya tetap kokoh dan menjawab kaisar bahwa bagaimana mungkin dia menyangkal atau mengutuk Yesus. Karena ia berpendapat Yesus tidak pernah mengecewakannya. Karena imannya ini ia dibakar hidup-hidup dan saat dibakar orang-

\footnotetext{
${ }^{12}$ Frans Wonatorei and Marciano Antaricksawan Waani, "Metode Penginjilan Yesus Kristus Menurut Injil Lukas," KHARISMATA: Jurnal Teologi Pantekosta (2021).

${ }^{13}$ AMOS WINARTO OEI, "DI ANTARA YANG DUNIAWI DAN YANG ROHANI: PENDETA/PENGINJIL DAN PANGGILANNYA," SOLA GRATIA: Jurnal Teologi Biblika dan Praktika (2020).
} 
orang menyaksikan bahwa tubuhnya yang terbakar tersebut berbau wangi dan tidak terluka, lalu ia ditusuk oleh seorang tentara dan mati syahid. Kisah kematiannya dituliskan atas permintaan jemaat Philomenium di Phyrigia. Dan beredar di jemaat di Asia Kecil. Mati syahidnya Polikarpus terjadi pada masa pemerintahan kaisar Antonius Pius, tahun 155/156.14

Jika melihat dan mempelajari akhir hidup para martir, seolah mereka hanya untuk mengalami penderitaan dan kematian saja, tetapi dari dahulu sampai sekarang tetap saja orang mau melakukan pengorbanan yang besar, beberapa orang pergi meninggalkan kehidupan yang mapan untuk menginjil keberbagai tempat, mengadakan perjalanan yangjauh. ${ }^{15}$ Setiap penginjil pasti akan diterangi oleh hikmat Roh Kudus sehingga hal tersebut menambah meningkatkan kemampuan sumber daya manusia. Bagi para penginjil merupakan pengetahuan dan kepekaan rohani, di dalamnya juga akan muncul keahlian dalam membangun hubungan antar manusia, juga ketahanan mental untuk berada di daerah-daerah yang sulit.

Rasul Paulus menguraikan bahwa Roh Kudus menyerap dalam sanubari orang percaya sebagai jaminan agar dapat menerima karya ilahi yang telah dipersiapkan bagi para penginjil atau orang percaya (2Kor. 1:21-22), hal ini yang membuat manusia memiliki kualitas yang lebih baik. Roh Kudus memampukan logika atau pikiran manusia yang begitu sederhana untuk memahami dan memberi kesanggupan akan hal-hal yang supranatural. Jadi Roh Kudus memampukan kita untuk menginjil meskipun mengalami penderitaan. ${ }^{16}$

Pekerjaan yang dilakukan Roh Kudus adalah tindakan inisiatif pribadi Roh Kudus dalam mengungkapkan karya-Nya sebagai kasih karunia Allah pada manusia. Adapun peranan Roh Kudus dalam mengubah kualitas sumber daya manusia menjadi lebih berkualitas adalah menuntun, mengubah dan memberikan nilai tambah dalam kualitas personil yang dipilih-Nya. Dalam praktiknya ketika memberikan pendidikan kepada orang percaya, Roh Kudus memberikan hikmat, pencerahan dan menjelaskan sehingga mendapat pengetahuan baru. Dalam hal mengadakan perubahan kualitas hidup Roh Kudus memampukan pikiran manusia memahami hal-hal yang tidak dipahami sebelumnya menjadi paham.

Semangat memberitakan Injil sangat erat kaitannya dengan kepercayaan orang-orang Kristen kepada Injil. Kepercayaan kepada Injil didasarkan pada karya Kristus, yang mati untuk dosa. Keselamatan di dalam Kristus adalah kekal dan sempurna, karena keselamatan diselesaikan sekali dan untuk semua hanya melalui kematian-Nya di kayu salib. Karena alasan inilah para penginjil tetap kuat dan teguh dalam iman. Selain itu Roh Kudus yang ada dalam mereka memberikan kekuatan secara supernatural dan itulah yang menyebabkan mereka bisa bertahan walaupun harus menerima penderitaan bahkan sampai mengalami kematian. ${ }^{17}$

\footnotetext{
${ }^{14}$ Wellem, "Polikarpus."

${ }^{15}$ Stott John R. W., Murid Radikal Yang Mengubah Dunia, ed. Santoso Milhan K., Ketiga. (Surabaya 60292: Literatur Perkantas Jawa Timur, 54. https://books.google.co.id/books?id=ucjsDwAAQBAJ\&printsec=frontcover\&dq=e+book+Penginjilan +202 $0 \& \mathrm{hl}=\mathrm{en} \& \mathrm{sa}=\mathrm{X} \& \mathrm{ved}=2 \mathrm{ahUKEwilqIm}$ thsDtAhUsyDgGHQN1CmkQ6AEwAHoECAMQAg\#v=onepage\& $\mathrm{q} \& \mathrm{f}=\mathrm{fa}$ lse.

${ }^{16}$ Martin Harun, "Craig S. Keener, Gift \& Giver: Mengenal Dan Mengalami Kuasa Roh Kudus, Terj. Helda Siahaan \& Nancy Pingkan Poyoh, Jakarta: Literatur Perkantas, 2015, 300 Hlm.," DISKURSUS JURNAL FILSAFAT DAN TEOLOGI STF DRIYARKARA (2015): 141.

${ }^{17}$ Asih Rachmani Endang Sumiwi, "Peran Roh Kudus Dalam Kehidupan Orang Percaya Masa Kini," Jurnal Teologi Gracia Deo (2018): 28.
} 

Tanama)

Apakah Tuhan membiarkan mereka akhirnya mati dengan mengenaskan, ya tetapi Tuhan tetap dalam rencana-Nya. Artinya setiap penderitaan, atau penyiksaan terhadap pemberita Injil memang sungguh diinginkan oleh masyarakat dunia yang tidak percaya, dan dengan caranya yang sangat keji para pewarta tersebut dibunuh secara sadis, ya jika kembali ke pertanyaan di manakah Tuhan saat itu? Tuhan tetap ada dan dengan kasihNya Ia melihat semua itu terjadi, Ia akan memberi hadiah hidup kekal kepada para martir bersama-Nya. ${ }^{18}$

Jika diperhatikan mengapa semua rasul menderita dalam penginjilan, baiklah lihat panggilan Paulus sebagai rasul adalah benar untuk memberitakan Injil. Sejak dia menerima amanat Yesus Kristus, misi penginjilan telah sepenuhnya digenapi. Dia berkomitmen penuh untuk penginjilan. Memberitakan Injil adalah tugas penting yang harus diselesaikan, jadi dia berkata, "Jika aku tidak memberitakan Injil, celakalah aku" (1Kor. 9:16). Namun, penginjilan tidaklah mudah. Ketika Paulus memberitakan Injil, dia akan menghadapi segala macam penderitaan. Tuhan telah mengatakan kepadanya: "Aku sendiri akan memberitahunya betapa banyak penderitaan yang harus dia tanggung untuk namaku" (Kis. 9:16). Paulus menderita dari misinya sebagai rasul dalam dua bentuk: sakit mental dan sakit fisik. Pertama-tama, rasa sakit mental adalah emosi emosional yang dialami Paulus ketika berurusan dengan orang-orang yang menolak khotbahnya.

Dalam misi Paulus, tidak semua orang dapat menerima semua khotbah Paulus. Beberapa orang secara terbuka menolak untuk memberitakan isinya (Kis. 3:50). Selain itu, dinamika kehidupan beriman yang dialami oleh jemaat yang mapan juga mempengaruhi pemikiran Paulus. Ketika dia tidak bersama orang-orang, dia harus menjawab pertanyaan-pertanyaan yang muncul dalam kehidupan orang-orang (lih. 1Tes 5: 1-11). Kedua, sakit fisik adalah kekerasan yang dialami Paulus ketika memberitakan Injil, seperti pemukulan, pemukulan, dilempari batu sampai mati, terbawa arus laut, bahaya pencuri, insomnia, kelaparan dan kedinginan (lihat 2Kor 11: 24-25). Selain itu, Paulus harus ditahan di penjara untuk misi penginjilan (lih. Fil. 1:13). Sebagai seorang penginjil, Paulus harus mengalami penderitaan mental dan fisik. Paul sangat bangga akan hal ini.

Melalui rasa sakit ini, dia menyadari bahwa memberitakan Injil adalah tugasnya dan dapat menghasilkan buah, sehingga memperkuat kepercayaan jemaatnya. Penderitaan yang dialami Paulus merupakan pertanda Tuhan, ia ingin mengajar dan mempersiapkan dirinya agar dapat membantu orang lain yang menderita (lih. 2Kor 1: 111). Melalui penderitaan semacam ini, secara tidak langsung Paulus memahami pengalaman jemaat yang menderita. Dengan kata lain, Tuhan ingin menunjukkan kepada Paulus bagaimana hidup dalam penderitaan itu. Paulus senang dengan rasa sakitnya, karena mereka mengungkapkan kuasa Tuhan, dan kuasa Tuhan disempurnakan dalam penderitaan manusia. Penderitaan di sini tidak berarti bahwa seseorang dengan sengaja menuangkan air pada dirinya sendiri untuk membawa keselamatan atas tindakannya, tetapi menderita bagi Kristus.

Paulus merasa kuat ketika dia menahan rasa sakit, karena dia menyadari bahwa dalam kelemahan ini, kekuatan Tuhan ada di dalam dirinya. Dengan kata lain, kelemahan ini memungkinkan Paulus untuk mengalami kuasa Tuhan, sehingga dia akan mampu menanggung semua penderitaan ini (1Kor. 12:10). Penderitaan yang dialami Paulus juga menunjukkan keaslian imannya, yang berarti bahwa Paulus menunjukkan kepada seluruh jemaat bahwa imannya berakar dalam pada dirinya sendiri dan membuat orang siap menanggung segala sesuatu, termasuk penderitaan. Dalam penderitaan iman, itu akan menguji sejauh mana orang dapat mempertahankan 
imannya. Allah akan memberikan keberanian kepada mereka yang mau berpegang teguh pada keyakinannya (bnd. 1Tes 2: 1-2). Akhirnya, Paulus menganggap penderitaan sebagai kesombongan, karena di sana ia mengalami pengalaman rasul sejati seperti Yesus Kristus.

Apa yang hendak kita pikirkan tentang kisah penderitaan Paulus? Pengalaman Paulus juga sangat relevan dengan situasi kita saat ini. Penderitaan dari penderitaan pengikut Kristus dapat membuat kita menjadi murid Kristus dalam hidup kita hari ini. Kita tidak boleh dipenjara atau dipukuli, tapi penderitaan kita, entah itu penyakit atau berbagai bentuk penolakan dalam kehidupan orang, selalu menghitamkan kehidupan kita. Jadi apa yang akan kita lakukan, kabur? Menghindar perintah Yesus? Tentu tidak. Memilih Kristus berarti siap untuk memikul salib, penderitaan dan bahkan kematian. Menurut Paulus, ini adalah cara iman Kristen. Paulus mengundang kita untuk menjadi Kristus dengan berbagi penderitaannya. Mengapa menderita dan harus menderita? Tentu saja, merupakan suatu pertanyaan bagi rata-rata orang Kristen seperti itu. Inilah yang harus diterima dan hidup sebagai pengikut Kristus; mereka yang mengikuti Kristus harus menyangkal diri mereka sendiri dan memikul salib-Nya.

\section{Respons Orang Percaya yang Terpanggil dalam Penginjilan}

Sebagai orang percaya, maka tugas penginjilan merupakan suatu keharusan yang diminta oleh Tuhan. Oleh sebab itu semua orang percaya harus siap melakukanya dan menguasai semua metode penginjilan dengan baik, sehingga dalam pelaksanaannya dapat menginjil dengan bijak. Yakni dengan cara menggunakan metode penginjilan yang sesuai dengan konteks lingkungan yang sedang dihadapi.

Tuhan Yesus sendiri secara tidak langsung menunjukan cara-cara penginjilan kepada para rasul. Beberapa bukti penginjilan telah dilakukan oleh Tuhan Yesus dalam bentuk penginjilan pribadi, yaitu kepada Nikodemus saat malam hari disampaikan kebutuhannya tentang kelahiran baru sebagai syarat masuk surga (Yoh. 3:1-13). Kemudian kepada wanita Samaria di pinggir sumur, Yesus memberitahukan kebutuhannya tentang air hidup yang tidak pernah habis, tetapi sampai pada kehidupan kekal (Yoh. 4:1-42) akan terus dipenuhi. Kemudian penginjilan kepada Zakeus di rumahnya, serta kepada penjahat yang disalib di sebelah-Nya Yesus menyampaikan kebutuhannya tentang pertemuannya dengan Tuhan Yesus di Firdaus, yaitu surga (Luk. 23:43). Semuanya dilakukan Tuhan Yesus dengan penginjilan secara pribadi.

Tindakan tersebut diikuti oleh murid-murid Yesus seperti ketika Andreas bertemu Mesias dan memberitakannya kepada Petrus (Yoh. 1:41), ketika Filipus bertemu Mesias dan memberitakannya kepada Natanael (Yoh. 1:45), juga ketika Filipus menginjili sidasida Etiopia (Kis. 8:35) dan ketika Petrus menginjili orang lumpuh di dekat gerbang bait Allah (Kis. 3:1-10).

Jadi sebagai respons orang percaya dan lahir baru tentu akan tertuju kepada tugas Amanat Agung untuk melakukan tidak saja secara pribadi melainkan juga secara masal. Seperti juga Yesus dan murid-murid-Nya kerap melakukan penginjilan di tengah orang banyak, hal itu menjadi contoh bagi para penginjil ketika Tuhan mengajar tentang Kerajaan Allah di hadapan ribuan orang. Kemudian ketika Yesus mengutus dua belas murid-Nya dan kemudian tujuh puluh murid untuk menginjil kepada banyak orang (Luk. 10:1-12). Petrus melakukan penginjilan di hadapan lebih dari 3.000 orang (Kis. 1), juga ketika Petrus bahkan melakukannya di hadapan lebih dari 5.000 orang (Kis. 4).

Dijelaskan bahwa tidak semua benih yang disemaikan jatuh ke tanah yang subur. Ada juga yang jatuh di tempat yang tidak subur dan tidak berbuah (Mat. 13), jadi jumlah juga dapat berpengaruh terhadap hasil. Karena dengan jumlah yang cukup akan 
terseleksi dan akan didapatkan pekerja-pekerja yang berkualitas untuk melakukan penginjilan yang lebih besar lagi.

Penginjil menyampaikan kabar baik seyogyanya dengan seluruh pengabdian diri dan mengandalkan kekuatan dari Tuhan. Risiko yang harus dihadapi oleh seorang penginjil tentu ada, bisa mendapat perlakuan sosial yang buruk dari lingkungan atau hingga penganiayaan. Namun seorang penginjil harus meyakini bahwa seluruh hidupnya ada dalam pengendalian daripada Tuhan. Oleh sebab itu orang percaya tidak perlu takut untuk terus memberitakan Injil, karena Tuhan berjanji akan selalu menyertai mereka (Mat. 28:19-20).

Penulis mengamati pula setiap penginjilan yang dilakukan secara luar biasa oleh para Rasul adalah karya Roh Kudus yang bekerja atas mereka, bagaimana hebatnya khotbah Petrus di hari Pentakosta sehingga orang-orang yang mendengar perkataannya itu di baptis dan hari itu jumlah mereka bertambah kira-kira tiga ribu jiwa (Kis. 2:41) tentu jumlah mereka lebih dari tiga ribu jiwa bahkan ketika Petrus dan Yohanes dihadapan Mahkamah Agama jumlahnya ditambah dengan lima ribu laki-laki.

Demikian juga penginjilan yang dilakukan oleh Paulus dengan hikmat kecerdasannya dia dapat masuk ke dunia orang-orang yang baru dikenalnya tetapi tidak ada masalah, inipun merupakan karya Roh Kudus yang bekerja atas diri Paulus dimana secara teliti, pengajarannya bisa diterima oleh penduduk di mana Paulus berada, ia menggunakan strategi dan hikmat dari Tuhan.

Paulus bertukar pikiran di tempat yang tepat yaitu sinagoge dengan orang-orang Yahudi dan pasar. Di kedua tempat ini memang salah satu tempat yang tepat untuk memberitakan sesuatu bahkan bersoal jawab menyampaikan pendapat. Itulah sebabnya pengajarannya diminati banyak orang sampai dia dibawa ke sidang Areopagus untuk diminta pendapatnya. Paulus tetap menghargai keyakinan yang lain, meskipun hal ini bukan berarti dia mempercayainya, tetapi dia memulai sebagai titik awal penginjilannya yaitu ketika ia berkata,"Kepada Allah yang tidak kamu kenal”. Di sinilah letak keahlian Paulus sebagai puncak teratas dari penginjilannya. ${ }^{19}$

Hal lain lagi contoh Paulus dalam penginjilan, seperti pada Kisah Para Rasul 18:910: "Pada suatu malam berfirmanlah Tuhan kepada Paulus di dalam suatu penglihatan: "Jangan takut! Teruslah memberitakan firman dan jangan diam! Sebab Aku menyertai engkau dan tidak ada seorang pun yang akan menjamah dan menganiaya engkau, sebab banyak umat-Ku di kota ini." Setelah menerima kepastian dari Tuhan sendiri, Paulus terus memberitakan Injil, meskipun dia mengalami tekanan dan penganiayaan dari orang-orang Yahudi. Di hadapan gubernur, mereka menuduh Paulus sebagai pembuat onar dalam membujuk orang untuk menyembah Tuhan dengan cara yang melanggar hukum. Tuduhan ini terkait dengan khotbah dan kesaksian Paulus tentang penyaliban Yesus sebagai Mesias. Namun, tuduhan mereka gagal meyakinkan gubernur, yang akhirnya memecat orang Yahudi dari pengadilan. Melalui cerita ini kita tahu bahwa meskipun biasanya tidak mudah untuk dipahami, namun pasti akan memenuhi jaminan keikutsertaan Tuhan dan janji perlindungan-Nya.

Walaupun kematian Paulus ini tidak dijelaskan tetapi tradisi menyebutkan bahwa dia dipenggal di Roma dan kematiannya dengan cara demikian merupakan bukti dia mati sebagai martir karena imannya kepada Yesus. Adapun kematiannya juga sebagai bagian dari pemusnahan orang Kristen yang diperintah oleh kaisar Romawi Nero setelah kebakaran besar di kota pada 64 Masehi. ${ }^{20}$

${ }^{19}$ Deni Alfian, "Model Toleransi Dalam Eksegese Khotbah Areopagus," Religió: Jurnal Studi Agamaagama (2016): 139.

${ }^{20}$ E.P Sanders, “St. Paul the Apostle Christian Apostle," Britannica. 
Petrus juga terpanggil sebagai pemberita Injil. Dia seorang murid pemberani yang dipilih Tuhan, yang selalu memberitakan Injil, meskipun terus mengalami penganiayaan. Berdasarkan sejarah, Petrus dibunuh oleh Kaisar Nero pada tahun 64 Masehi, setelah ada suatu kebakaran besar di Roma. Sebuah catatan apokrip memberi penjelasan bahwa Simon Petrus disalibkan secara berbeda yaitu terbalik karena dia tidak mau menganggap diri sama seperti junjungannya yaitu Yesus. Tetapi dikatakan juga bahwa Tentara Romawi suka melakukan percobaan dalam berbagai bentuk penyaliban. Sejarawan Yahudi-Romawi Yosefus, menulis tentara Romawi tidak selalu menyalibkan orang "dengan posisi menghadap ke atas", dan prajurit-prajurit itu mencoba berbagai posisi untuk sekadar hiburan. ${ }^{21}$

Rasul Andreas adalah salah seorang murid Kristus dan dia adalah saudara laki-laki Simon Petrus. Rasul Andreas melakukan penginjilan di daerah Laut Hitam. Dia dinyatakan meninggal tahun 60-70AD di Patras, Achaia, Yunani sekarang. Akhir dari pelayanannya dia mati sebagai martir diikat dikayu sebagai Salib latin, mirip dengan Yesus tetapi dengan salib berbentuk $\mathrm{X}$ atau saltire yang kemudian dikenal sebagai Salib Rasul Andreas, dikatakan salib jenis ini dipakai atas permintaannya sendiri karena dia menganggap tidak layak untuk disalibkan sama seperti Yesus. ${ }^{22}$

Murid-murid yang lain mengalami hal yang sama seperti Matius, menurut sejarah ia menjadi martir karena disiksa kemudian dibunuh menggunakan Pedang di daerah Etiopia. ${ }^{23}$ Yakobus yang merupakan saudara tiri dari Yesus dan pemimpin gereja di Yerusalem, menjadi martir dengan sangat cukup mengenaskan, Yakobus disiksa dilempar dari atap bait Allah. ${ }^{24}$ Yohanes, penulis injil Yohanes, pernah digoreng hiduphidup pada kuali minyak yang mendidih, tetapi dia selamat dan tidak terluka karena pertolongan Tuhan. Selanjutnya Yohanes dibuang ke sebuah pulau. ${ }^{25}$ Filipus merupakan murid Yesus yang banyak dikisahkan dalam injil Yohanes, dia martir seperti Simon Petrus disalibkan dengan kepala berada di bawah kaki di atas. ${ }^{26}$

Bartolomeus, ia wafat sebagai martir di Armenia karena mendapat hukuman cambuk bertubi-tubi hingga kulit tubuhnya terkelupas, terkoyak di seluruh tubuhnya. ${ }^{27}$ Lukas menjadi martir tubuhnya digantung di Yunani, setelah ia memberitakan Firman Allah kepada orang-orang yang belum percaya dan mengenal Tuhan. ${ }^{28}$ Markus menjadi martir dengan cara yang mengerikan di Alexandria (Mesir), karena tubuhnya yang masih hidup ditarik dengan kuda di jalan yang berbatu-batu sampai meninggal dunia. ${ }^{29}$ Thomas, menjadi martir dibunuh dengan tusukan tombak di India. ${ }^{30}$ Yudas, saudara Yesus dihukum mati dengan panah, karena ia tidak bersedia untuk mengingkari Yesus. ${ }^{31}$ Matias, dia adalah pengganti Yudas Iskariot menjadi martir karena dirajam dengan pedang dan pada akhirnya kepalanya dipenggal. ${ }^{32}$

Penulis mendapatkan bahwa setiap penginjil begitu berapi-api dalam menyampaikan berita tentang Injil dan tentang Yesus Sang Juruselamat, mereka tetap

${ }^{21}$ Ryan Nelson, "How Did the Apostles Die? What We Actually Know," Bible Jeffrey Krans.

${ }^{22}$ Jon Rogers, "SAINTLY BEHAVIOUR Where Did St Andrew Die, What Was His Cause of Death and When Did He Become Scotland's Patron Saint?," Scottish Sun.

23PastiMati.com, "Kisah Kematian Tragis Ke 12 Murid Yesus," Khusus Jurnal.

${ }^{24}$ Ibid.

25Ibid.

26Ibid.

27Ibid.

${ }^{28}$ Ibid.

${ }^{29}$ Ibid.

30Ibid.

31 Ibid.

32Ibid. 
bersemangat tidak memperdulikan nyawa mereka. Bagi sebagian besar manusia yang tidak memiliki keyakinan, kematian adalah suatu penderitaan atau kengerian dan bahkan merupakan sesuatu yang sangat ditakuti, mungkin akhir segalanya. Tetapi Paulus pernah berkata tentang hidup adalah Kristus dan mati adalah sebuah keuntungan (Flp.1:12-26). Jika dilihat dari perpektif Alkitab dalam Ibrani 9: 27 sama seperti manusia ditetapkan untuk mati hanya satu kali dan sesudah itu dihakimi. Hal itu berarti bahwa setiap orang yang percaya kepada Kristus harus menghadapi pengadilan yang merupakan kelanjutan setelah kematian.

Jadi kata-kata Paulus tentang "karena bagiku hidup adalah Kristus dan mati adalah keuntungan" merupakan bukti penyangkalan diri Paulus dan kepatuhannya kepada Allah. Kesadaran Paulus dan rasa berdosanya sebagai penyiksa jemaat tak membuat dirinya terjebak dalam bentuk mengasihani diri, tetapi anugerah Tuhan yang meleburkan kesombongannya memperbarui semangat penginjilannya. ${ }^{33}$

Berdasarkan banyak hal-hal yang telah disebut di atas maka jelaslah bagi orang percaya yang terus melakukan kehendak-Nya terutama dalam penginjilan tidaklah perlu takut. Ketika Tuhan memberikan perintah untuk menginjil, maka Tuhan yang menyertai dan memberikan kekuatan bagi mereka yang mentaatinya. Bagi orang-orang yang membaca dan mendengarnya, penderitaan mereka seperti suatu kengerian, tetapi bagi mereka yang mengalaminya menjadi suatu kebahagiaan. Oleh sebab itu respons orang percaya haruslah terus taat untuk melakukan penginjilan di mana pun Tuhan tempatkan.

Petrus memberikan penghiburan kepada orang-orang yang membaca suratnya. Dia menyatakan bahwa penderitaan yang dialami di dalam Tuhan adalah karunia. Seseorang yang dipanggil untuk mengikut Tuhan tidak hanya untuk menikmati berkat yang ada di dalamnya, melainkan turut menderita. ${ }^{34}$ Penderitaan karena melakukan perbuatan baik bukanlah kesalahan dari orang yang mengalaminya. Pendertiaan tersebut adalah anugerah yang ikut dialami orang yang telah percaya kepada Yesus.

Yesus telah memberikan peringatan kepada para pengikut-Nya, bahwa dunia akan membenci mereka seperti dunia membenci Yesus. Kebencian itu tidak bisa dihindari lagi, karena orang yang mengikut Yesus, akan mengalami apa yang Yesus telah alami. Yesus bukan dari dunia, sehingga dunia membencinya. Kebencian itu akan berlanjut kepada pengikut-Nya, sebab mereka akan menyangkal nilai dunia dan beralih status menjadi pengikut Yesus. ${ }^{35}$

Pemanggilan seseorang menjadi penginjil, akan disertai dengan panggilan untuk menderita. Ketika Yesus memanggil murid-murid-Nya, Dia langsung menyatakan bahwa mereka harus menyangkal diri, memikul salib, lalu mengikuti Dia. Keputusan untuk mengikut Yesus dan melakukan perintahnya, berarti keputusan untuk menderita. Keputusan untuk mengikut Yesus merupakan tindakan yang membutuhkan komitmen. ${ }^{36}$

\section{Kesimpulan}

Penginjilan dan penderitaan memiliki kaitan yang sangat kuat. Kematian para martir telah membuktikan betapa kuat keimanan mereka, walaupun pada akhirnya mereka harus kehilangan nyawa. Hal ini bukan berarti Tuhan tidak menyertai mereka,

\footnotetext{
${ }^{33}$ Romianna Magdalena Sitompul, "Makna Perkataan Paulus Tentang Hidup Adalah Kristus Dan Mati Adalah Keuntungan Berdasarkan Filipi 1:12-26," Jurnal Jaffray (2017): 154.

${ }^{34}$ Made Nopen Supriadi and Iman Kristina Halawa, "MAKNA PENDERITAAN KRISTUS DALAM 1 PETRUS 2:18-21," Manna Rafflesia 5, no. 1 (2018): 69-91, https://journals.sttab.ac.id/index.php/man_raf/article/view/99. ${ }^{36}$ Ibid.

${ }^{35}$ Bora, "Keserupaan Dengan Yesus Dalam Penderitaan, Kesengsaraan Dan Kematian-Nya."
} 
justru karena Tuhan menyertai maka secara iman mereka menjadi lebih kuat dan bertahan sampai akhir hidupnya tanpa menyangkal Kristus. Itulah bentuk penyertaan Tuhan dalam pewartaan berita keselamatan. Mereka berbahagia dapat melakukannya untuk Tuhan dengan seluruh tubuh, jiwa dan rohnya. Penderitaan yang dirasakan pada semua peristiwa justru membuat mereka semakin merasa dekat akan cinta kasih Allah yang begitu besar. Kematian adalah suatu keuntungan karena mereka akan mendapat suatu mahkota dari Tuhan (Why. 2:10c) "Hendaklah engkau setia sampai mati, Aku akan mengaruniakan kepadamu mahkota kehidupan." Jika kematian adalah sebuah keuntungan, maka para penginjil sudah mendapatkannya, karena mereka bertahan sampai pada kesudahan dari pertandingan imannya. Penginjilan membutuhkan pengorbanan sama seperti Kristus telah berkorban untuk keselamatan umat manusia.

Penderitaan dalam penginjilan merupakan sesuatu yang harus dihadapi. Seseorang yang melakukan penginjilan akan memberitakan mengenai Yesus dan karyanya, sehingga dia akan membawa berita mengenai Tuhan yang bukan berasal dari dunia. Dunia tidak akan menerima berita tersebut. Hal inilah yang menyebabkan timbulnya penderitaan dalam penginjilan.

\section{Referensi}

Alfian, Deni. "Model Toleransi Dalam Eksegese Khotbah Areopagus." Religió: Jurnal Studi Agama-agama (2016).

Alfons, Daud, Pandie Nidia, and Lina Ardela. URGENSI PENGINJILAN SEBAGAI TANGGUNG JAWAB GEREJA. APOLONIUS : Jurnal Teologi Dan Pendidikan Kristen, 2020.

Bora, Lewi Nataniel. "Keserupaan Dengan Yesus Dalam Penderitaan, Kesengsaraan Dan Kematian-Nya." Manna Rafflesia 7, no. 1 (2020). https://journals.sttab.ac.id/index.php/man_raf/article/view/127.

Harun, Martin. “Craig S. Keener, Gift \& Giver: Mengenal Dan Mengalami Kuasa Roh Kudus, Terj. Helda Siahaan \& Nancy Pingkan Poyoh, Jakarta: Literatur Perkantas, 2015, 300 Hlm." DISKURSUS - JURNAL FILSAFAT DAN TEOLOGI STF DRIYARKARA (2015).

Hengki, Wijaya, and Nyoman Lisias F. Dju. "Pengajaran Tentang Panggilan Berdasarkan Kitab Yunus." ResearchGate (2015).

Hidayat, Elvin Atmaja. "Iman Di Tengah Penderitaan: Suatu Inspirasi Teologis-Biblis Kristiani." Melintas An International of Philosophy and Religion 32, no. 3 (2016): 285-308. https://journal.unpar.ac.id/index.php/melintas/article/view/2695. Illu, Jonidius. "PENDERITAAN DALAM PERSFEKTIF ALKITAB.” Luxnos: Jurnal Sekolah Tinggi Teologi Pelita Dunia 5, no. 2 (2019): 101-109. https://luxnos.sttpd.ac.id/index.php/20_luxnos_20/article/view/19.

Jon Rogers. "SAINTLY BEHAVIOUR Where Did St Andrew Die, What Was His Cause of Death and When Did He Become Scotland's Patron Saint?" Scottish Sun.

Mostert Bennie. When God Renews People. First. Christian Art Publishers, 2011.

OEI, AMOS WINARTO. "DI ANTARA YANG DUNIAWI DAN YANG ROHANI : PENDETA/PENGINJIL DAN PANGGILANNYA.” SOLA GRATIA: Jurnal Teologi Biblika dan Praktika (2020).

PastiMati.com. "Kisah Kematian Tragis Ke 12 Murid Yesus.” Khusus Jurnal.

Ryan Nelson. "How Did the Apostles Die? What We Actually Know." Bible Jeffrey Krans. 
PENDERITAAN DALAM KONTEKS PENGINJILAN (Tri Prapto Suwito, Yanto Paulus Hermanto, Yulia Jayanti

Tanama)

Sanders, E.P. "St. Paul the Apostle Christian Apostle." Britannica.

Sihombing, Warseto Freddy. "Penderitaan Orang Percaya Dalam Surat 1 Petrus." KERUGMA: Jurnal Teologi dan Pendidikan Agama Kristen (2019).

Sitompul, Romianna Magdalena. "Makna Perkataan Paulus Tentang Hidup Adalah Kristus Dan Mati Adalah Keuntungan Berdasarkan Filipi 1:12-26." Jurnal Jaffray (2017).

Soesilo, Yushak. "Pentakostalisme Dan Aksi Sosial: Analisis Struktural Kisah Para Rasul 2:41-47." DUNAMIS: Jurnal Teologi dan Pendidikan Kristiani (2018).

Stephanus, Djuwansah Suhendro P. "Mengajarkan Penginjilan Sebagai Gaya Hidup Orang Percaya." Redominate (2019).

Stott John R. W. Murid Radikal Yang Mengubah Dunia. Edited by Santoso Milhan K. Ketiga. Surabaya 60292: Literatur Perkantas Jawa Timur, 2018.

Sumiwi, Asih Rachmani Endang. "Peran Roh Kudus Dalam Kehidupan Orang Percaya Masa Kini." Jurnal Teologi Gracia Deo (2018).

Supriadi, Made Nopen, and Iman Kristina Halawa. "MAKNA PENDERITAAN KRISTUS DALAM 1 PETRUS 2:18-21.” Manna Rafflesia 5, no. 1 (2018): 69-91. https://journals.sttab.ac.id/index.php/man_raf/article/view/99.

Wellem, F. D. "Polikarpus." BPK Gunung Mulia.

Wonatorei, Frans, and Marciano Antaricksawan Waani. "Metode Penginjilan Yesus Kristus Menurut Injil Lukas." KHARISMATA: Jurnal Teologi Pantekosta (2021).

Zaluchu, Sonny Eli. "Strategi Penelitian Kualitatif Dan Kuantitatif Di Dalam Penelitian Agama." Evangelikal: Jurnal Teologi Injili dan Pembinaan Warga Jemaat 4, no. 1 (2020): 28-38. 